\title{
O PODER NO TEXTO
}

Elisabet Gonçalves Moreira

Lenira Marques Covizzi (1)

"La Dominante" é um texto de 1935. E, as tres primeiras etapas da pesquisa formalista, são assim brevemente caracterizadas: 1 . análise dos aspectos fônicos 2 . problemas do sentido (base: poética) 3 integração do som e do sentido na obra, entendida como um todo indivisível. Para falar primariamente: 1 significante $(+) 2$. significado $(=) 3$. significação.

E é aqui, em 3., que aparece o conceito de dominante, que, "peut se définir comme l'élément focal d'une oeuvre d'art: elle gouverne, détermine et transforme les autres éléments. C'est elle qui garantit la cohésion de la structure." (2)

No caso da literatura: função manifesta, sem implicar em negativização ou extermínio das outras funções, que coexistem. Em caráter recessivo, para utilizar terminologia biológica. Dizendo de outra maneira: trata-se da função que está definindo, determinando uma estrutura linguística de maneira não exclusiva; apesar de as outras funções da linguagem continuarem presentes em caráter virtual. De estarem implícitas.

A definição da obra de arte diante de outros valores culturais depende do conceito de dominante que a define.

(1) - Este texto foi preparado para apresentação em seminário do curso de pós graduação Poesia e Históricidade sob a responsabilidade do p:of. dr. João Alexandre Costa Barbosa (Teoria Literária e Literatura Comparada), no $1^{9}$ semestre de 1974. Redigido e apresentado por Lenira Marques Covizzi, ocupa-se do conceito de dominante em literatura, basado nos seguintes textos:

Jakobson, Roman-"La dominante" p. $145 / 151$ in Questions de Poétique Paris, Seuil 1973.

Jakobson, Roman-"Linguística e Poética" p. 118/162 in Linguística $e$ Comunicação Cultrix, São Paulo 1969. ... .. obs: Muito boa manipulação dos conceitos de dominante e da função poética da linguagem pode ser vista no texto de Iumna Maria Simon, Drummond, uma poética do risco, ed. Ática, col. Ensaios 43, 210 pp., 1978.

(2) - Jakobson, Roman "La dominante" p. 145. 
Não monismo, nem mecanicismo, mas articulação, já implícita no batismo: hierarquia. Não despotismo, nem agregação ou paralelismo, mas articulação.

Deixando o idealismo e sua implicação de absoluto, mas relativamente realista - e, nesse sentido precisa ser encarada a praxis jakobsoniana - propõe a consideração das funções da linguagem em termos articulatórios: "S'opposant à la fois au monisme intégral et. au pluralisme intégral, il existe un point de vue qui, tout en étant attentif aux multiples fonctions de l'oeuvre poétique, tient compte de sa cohésion, en d'autres termes, de ce qui confère à l'oeuvre poétique son unité et son existence même." (3) Jakobson, depois de definir, didaticamente, o conceito de dominante, numa redundância de que já se pode valer, sintetiza: "La dominante spécifie l'oeuvre." (4)

Daí podermos concluir que a dominante pode ser entendida como a "differentia specifica" de todo objeto, de qualquer estrutura. Em nosso caso: preocupação com a "differentia specifica" - de caráter linguístico — da literatura no seu caráter criador. Assumindo aqui, etimologicamente, poiesis enquanto criação; que, no caso da literatura pode ser entendida como uma violência organizada erigida sôbre $/ \mathrm{com}$ a linguagem quotidiana. Jakobson esclarece, exemplificando: o caráter específico da linguagem versificada é o seu esquema prosódico (pronunciação exata: acentos/sons): verso é verso. Diríamos: o caráter específico da prosa de ficção, seu esquema prosaico, vulgar, "sem elevação": prosa é prosa.

De que natureza é essa dominante? Um elemento auditivo (sonoro) ao nível da música, pictural ao nível da pintura, linguístico ao nível da literatura. Uma parte (um elemento), que influencia as outras (os outros elementos)

Só que não é tão simples assim a conceituação dêsse elemento dominador. Não basta dizer: é verso, ou, é prosa. Esses conceitos implicam um sistema de valores: maiores, menores, dominados, dominadores em cada caso individual, um dado período e uma dada tendência literária. E ainda Jakobson quem exemplifica: poesia checa do século XIV: marcada pela rima (a que não a tivesse: não verso), poesia checa da segunda metade do XIX: império do esquema silábico (aqui, verso livre $=$ arritmia), poesia checa moderna : verso livre= entonação.

Nos tres casos, os mesmos elementos, mas diferente hierarquia de valores. "Ce sont précisément ces éléments spécifiques qui déterminent le rôle et la struture des autres constituants." (5)

(3) - Jakobson, Roman "La dominante" p. 147.

(4) - Jakobson, Roman, "La dominante" p. 145

(5) - Jakobson, Roman, "La dominante" p. 146. 
E, a dominante existe não só no nível da produção de um artista individual, do molde de uma escola poética, mas também em tôda a arte de uma época enquanto um todo.

Resumindo: dominante numa obra,

em toda uma produção individual,

no cânone de uma escola,

na arte de toda uma época.

Por exemplo: Renascença: critério estético: o visual.

Romantismo: critério estético: a música (o sonoro, o auditivo)

Realismo: critério estético: a arte da linguagem.

"Cette organisation autour d'une dominante qui, en realité, est extérieure à l'essence même de l'oeuvre poétique pèse sur la structure du poème en ce qui concerne sa structure phonique, sa structure syntaxique, et son champ rhétorique; elle modifie les critères métriques et strophiques du poème, sa composition." (6)

Quando Jakobson, em 1960, amplia o modelo tradicional da linguagem, que, segundo Bühler, contava com tres funções: predomínio do remetente (emotiva) - 1 o pessoa; predomínio do destinatário (conativa) $-2^{\circ}$ pessoa; predomínio do contexto (referencial) 39 pessoa, para desfibrá-la em seis: predomínio do contato (função fática), do código (função metalinguística) e da mensagem (função poética), fica mais fácil conseguir sacar, dar-se conta da "coerência e complexidade" que é a obra de arte literária, para usar da sintética reiteração de Wellek e Warren na sua Teoria da Literatura.

Não é possível reduzir qualquer linguagem que seja a uma função. Mecanicismo insustentável. Nem fazer o jogo inverso, assumindo mecanicistamente em toda linguagem a existência paralela de todas as funções. A resolução do impasse é dada num esquema hegeliano em primeira instância, e que, segundo Foucault, faz a obra, funda-a monumento e não documento, quando Jakobson diz: "S'opposant à la fois au monisme intégral et au pluralisme intégral, il existe un point de vue qui, tout en étant attentif aux multiples fonctions de l'oeuvre poétique, tient compte de sa cohésion, en d'autres termes, de ce qui confère à l'oeuvre poétique son unité et son existence même." (7) Wellek, diria, em outros termos, "coerência e complexidade."

Daí concluirmos que, em termos de ser uma estrutura verbal característica, a obra de arte é aquela cuja função dominante - mas

(6) - Jakobson, Roman, "La dominante" p. 146.

(7) - Jakobson, Roman, "La dominante" p. 147. 
não a única - é a poética. Mais tarde, em Linguística e Poética, Jakobson esclarece: "Qualquer tentativa de reduzir a esfera da função poética à poesia ou de confinar a poesia à função poética seria uma simplificação excessiva e enganadora. A função poética não é a única função da arte verbal, mas tão sòmente a função dominante, determinante, ao passo que, em todas as outras atividades verbais, ela funciona como um constituinte acessório, subsidiário. Com promover o caráter palpável dos signos, tal função aprofunda a dicotomia fundamental de signos e objetos." (8)

As marcas da função estética (poética) não são imutáveis, e, nem sempre idênticas. Elas são diferentes de obra para obra, de autor para autor, de gênero para gênero, de época para época dentro de uma mesma arte. apesar de muitos elementos indispensáveis $\mathrm{e}$ distintivos que as fundam poesia, linguagem criadora, não sendo confundida com qualquer outra finalidade. Por exemplo a comunicativa, a referencial ou a metalinguística.

Falando em hierarquia já é possível perceber — visual e esquematicamente, no exemplo - a hierarquia das funções na linguagem poética, considerando o signo que ela é, e a designação na qual se estriba:

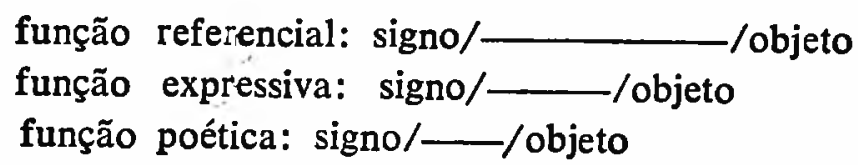

Linguagens que se encavalam, esbarram uma na outra, apesar de cada uma ser uma, sem se identificar

O conceito de dominante e o da evolução literária, evolução da forma poética segundo as pesquisas formalistas, não implica no desaparecimento de certos elementos e no surgimento de outros, mas de deslizamentos, escorregadelas entre "les relations mutuelles des divers éléments du système, autrement dit, d'un changement de dominante" (9) Tal colocação faz-se possível pela compreensão formalista da obra poética como sistema estruturado enquanto ordenado e hierarquizado de maneira regular de procedimentos artísticos. Logo, evolução é uma mudança na hierarquia e não, preconceituosamente, um valor positivo. "La hiérarchie des procédés artistiques se modifie dans le cadre d'un genre poétique donné; la modification en vient à affecter la hiérarchie des genres poétiques et, simultanément, la distribu-

(8) - Jakobson, Roman "Linguística Poética" p. 128.

(9) - Jakobson, Roman "La dominante" p. 148. 
tion des procédés artistiques parmi les autres genres. Des genres qui étaient, à l'origine, des voies d'interêt secondaire, des variantes mineures, viennent à présent sur le devant de la scène, cependant que les genres canoniques sont repoussés à l'arrière-plan." (10)

Evolução ao nível das modificações entre as relações das diferentes artes: a importância do desenho, por exemplo, para a poesia concreta.

Evolução: relação entre as artes e outros domínios culturais próximos à ela (principalmente literatura e outras mensagens verbais); ou " des modifications dans les relations entre les arts et les autres domaines culturels qui leur sont liés de près... (11) Exemplo: a memória: entre a história e a arte?

Constatação teórica que altera, modifica a avaliação, a abordagem crítica do objeto. Valores diferentes, em sistemas diferentes. $\mathrm{Na}$ épocá em que surgem, subvertem o estabelecido podendo ser considerados negativos. Só depois chega-se à conclusão que instituiu-se uma nova concepção da forma poética. Daí poder-se concluir que o conceito de evolução não se reduz, como costuma ser considerado primeiramente, à ordem histórica: "mais que le changement est aussi un fait synchronique directement vécu et une valeur artistique pertinente." (12)

Para todo receptor são conferidas e exigidas duas ordens de realidade em qualquer tipo de objeto artístico: a forma, o cânone, o modelo tradicional, e o seu desvio. "C'est sur la toile de fond de la tradition que l' innovation est perçue. Les études formalistes ont démontré que c'est cette simultanéité entre le maintien de la tradition et la rupture avec la tradition qui forme l'essence de toute innovation en art." (13)

As considerações acima nos permitem segmentar teoricamente - através da pressuposição interna, é claro _-, as não só possíveis mas necessárias abordagens da obra de arte literária em dois ramos: um, que se preocuparia, de maneira mais evidente com a evolução, a história literária, ou a diacronia do objeto. Só que, essa diacronia só se realiza através do objeto construído. Não podemos então sintetizar essas duas abordagens de maneira simplista em estática (ao nível da Teoria) e dinâmica (ao nível da História) porque essas duas realidades só existem em função: uma da oütra. Jakobson diz mais clara-

(10) - Jakobson, Roman "La dominante" p. $148 / 9$.
(11) - Jakobson, Roman "La dominante", p. 150.
(12) - Jakobson, Roman "La dominante" p. 150.
(13) - Jakobson, Roman "La dominante" p. 151. 
mente em Linguística e Poética: "A poética sincrônica, assim como a Linguística sincrônica não deve ser confundida com a estática; toda época distingue entre formas mais conservadoras e mais inovadoras. Tôda época contemporanea é vivida na sua dinâmica temporal, e, por outro lado, a abordagem histórica, na Poética como na Linguística, não se ocupa apenas de mudanças, mas também de valores contínuos, duradouros e estáticos. Uma poética histórica ou uma história da linguagem verdadeiramente compreensiva é uma superestrutura a ser edificada sôbre uma série de descrições sincrônicas sucessivas." (14)

Ainda, decorrência esperada, é também o caráter de historicidade da Crítica, que se funda na História (D) e na Teoria Literária (S), não se confundindo com elas, assim como o caráter da obra de arte, um objeto específico: entre a realidade e a irrealidade; inegavelmente, um objeto-historicidade: entre a história e a imaginação, inventividade, liberdade criadora; entre a referência e ela própria (a referência que é ela própria); entre a realidade da história - sua referência e a sua própria - seu código: historicidade, enfim, realidade da obra de arte literária: balanço entre linguagem e metalinguagem. (15)

Realidade que é a sua historicidade, que é internalização objectual (o objeto literário) do factual; e não fazer dela, confiná-la com um "humanismo transcendental" como diz Lévi-Strauss em La pensée Sauvage.

Resumindo: não existe uma relação de despotismo absoluto, mas esclarecido, de dominações diferentes (D) em épocas diferentes; pela implicação. Aqui fica claro como a Diacronia pressupõe e está implicada na Sincronia.
A contrária é verdadeira.
Não absolutismo.
Despotismo. Esclarecido.

Adendo.

Caudas Aulete - p. 2608/2609

- Historicidade - qualidade do histórico.

- Historicismo - consideração de um problema unicamente do ponto de vista do seu desenvolvimento históri-

(14) - Jakobson, Roman "Linguística e Poética" p. 121.

(15) - Comparar as diferenças - e semelhanças - da composição do texto poético, apresentadas aqui a partir de Jakobson, com a ecriture (Barthes), a produção textual (Kristera) e a mensagem como uma "dinâmica produtiva de texto poético, apresentadas aqui a partir de Jakobson, com a écriture (Barthes), (em especial o Cap. II. "Crítica e Escritura"), Ensaios 45, Ática- SP . 1978, $158 \mathrm{pp}$. 
co, nada se podendo nele modificar deliberadamente nem interpretar de outra forma do que na sua história.

- História

- narração e conhecimento dos acontecimentos sociais cujo conjunto constitui a tradição.

- Focal - adjetivo, relativo ao foco.

- Foco

- parte do forno que contem o combustível; fornalha do cachimbo (Geom.)

Ponto interior de algumas curvas de onde saem os raios vetores ou linhas que determinam as figuras por eles formadas. (Fís.)

Ponto onde convergem os raios de luz, depois de refratados em uma lente ou de refletidos em um espelho.

O ponto onde se vê a imagem de um objeto colocado diante de um espelho.

Fogacho que se acende de noite para servir de guia aos marinheiros.

Ponto de reunião, sede principal, centro de qualquer coisa. (Fig.)

Lugar de onde saem emanações.

Centro, ponto de convergência .

Sede principal de qualquer doença. (Med.).

Síntese de "La dominante" (16)

I - Tentativa de definição

a) NĀO

A dominante não anula, não negativiza, não destrói todos os outros elementos da obra de arte,

b) SIM

apesar de ser um elemento que governa, determina, transforma todos os outros elementos.

c) Só assim recupera a noção de todo da obra de arte: especificidade; coesão da estrutura.

(16) - Síntese realizada e apresentada por Elisabet Gonçalves Moreira. 
II - Natureza da dominante: sempre um elemento linguístico (um entre outros); função: especificar o caráter poético da linguagem.

III - Valor: não monismo, nem pluralismo, mas articulação: todas as funções coexistem mas uma é a dominante.

IV - Evolução literária

a) Evolução segundo o formalismo russo: sistema estruturado.

b) Logo, evolução literária: mudança na hierarquia do sistetema.

Evolução como modificação de relações entre as diferentes artes.

d) Evolução como modificação entre as artes e os outros conjuntos culturais vizinhos.

Logo: evolução não tem só caráter diacrônico.

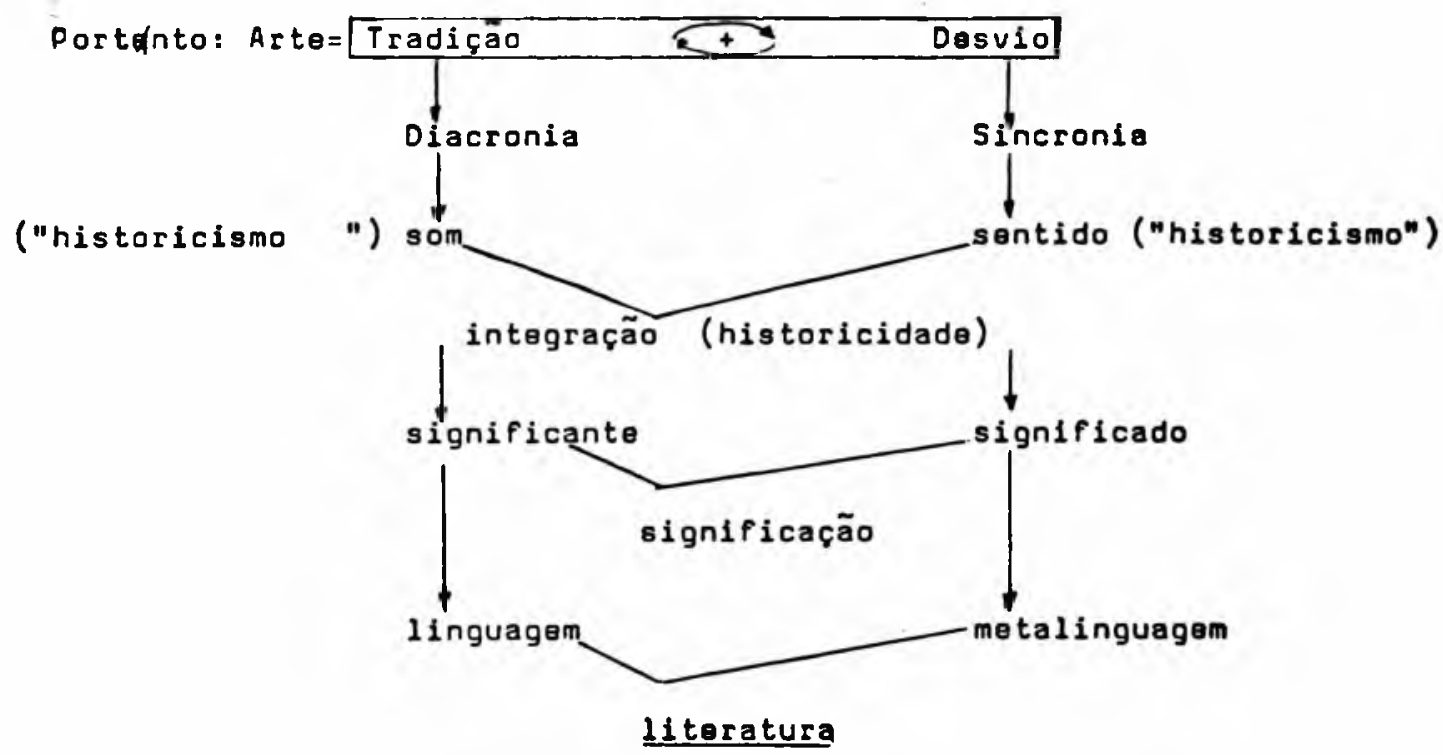

